\title{
Leadership, Professional Development and Teachers' Practice in Bedouin High Schools
}

\author{
Salih Alasad \\ West University of Timisoara, Timisoara, Romania
}

\begin{abstract}
The purpose of this paper is to explore the Bedouin educational system from the leadership context and its relation with professional development and to test professional development impact on teachers' practice. The research relies on the theory of full range leadership model and professional development and teaching practice. Design/methodology/approach - the questionnaires assessing the variables of interest were completed by 306 teachers in 22 Bedouin high schools in the Negev in south of Israel, in addition to an interview with 10 principals. As results of the study, hypotheses which expect a positive relationship between transformational and transactional leadership and professional development have been rejected. On the other hand hypothesis that expects no relationship between laissez-faire leadership and professional development and hypothesis which expects a positive relationship between professional development and teachers practice have been accepted.
\end{abstract}

Keywords: Bedouin, leadership, professional development, teachers practice

\section{Introduction}

The Bedouin society today is in the transitional process from traditional social life to the life of a modern society, although about a half of them lived in temporary villages.

In modern life, the education is one of the main and essential aspects for the cultural design, personal and group development, social, economic, stratification and politics in any society.

There are two key factors influencing effective education: The first major aspect of school management is leadership, because leadership is a main factor that contributes significantly to the overall well-being of organizations and nations. The second important factor is professionalism of teachers. School effectiveness and professional development are closely related. It is within this context that the importance of leadership in improving the quality of schools is identified as a crucial element therefore; there is a place to explore and to analyze the educational system from a leadership context and its relation with professional development and the professional development impact on teachers' practice.

\section{Theatrical Literature-Leadership Styles}

\section{Transformational Leadership}

Transformative leaders are characterized as managerial leaders who focus on supervising, organizing, and performing staff. The changes that are made on the subordinates by the transformative leader are changes of a

Salih Alasad, Ph.D., School of Business Administration, West University of Timisoara, Timisoara, Romania.

Correspondence concerning this paper should be addressed to Salih Alasad, P.O. Box 161, Lakia 8499100, Israel. 
higher status and may include a change of values and beliefs. The transformative leader (designer) has the ability to shape the expectations of the people and make them new expectations which they did not have before from themselves at the beginning of interaction with the leader. Transformational leadership is the leader's ability to generate enthusiasm, emotional involvement, and commitment from subordinates and organizational issues. He has a clear vision that has been formulated in such a way that the last of the people in their organizations succeeded in implementing this vision and becoming part of it.

\section{Transactional Leadership}

The transactional leadership is a style of leadership whose purpose is driven by obedience to the leader's orders through punishment and retribution. He does not act to change the future; but they only seek to maintain the same. These leaders look and study the work of their followers to find flaws and problems. This leadership style is effective and suitable for emergencies and crisis situations, in addition to cases where projects should be carried out in a certain manner.

\section{Laissez-faire Leadership}

The most prominent characteristic of this leader's behavior is avoidance from taking a stand, from decisions making, and actually from any action. Laissez-fair style is defined as "Abdicates responsibilities avoid making decisions". This is not an active leadership which reflects each attempt not to affect. The subordinates of this leader don't receive guidance or support, and typically show indifference and carelessness and will tend to focus on achieving their personal goals, even if they are in conflict with the objectives of the organization or the group.

\section{Professional Development}

The human resource is the most important resource in the development and promotion of the organization, so investing in teacher training may have a more positive effect than investing in physical resources.

Professional development is defined as an ongoing process of development which occurs in constant interaction between the individual and the environment in which he functions (Hassel, 1999). For example, researchers speak about a professional career, during which changes in thought and behavior occur in professional practice. These changes derive mainly from experiential learning processes and are directed. They believe that the acquisition of the teaching profession is a broad process which persisted in childhood, but continued during the teacher's experience as a student and finally as an actual teacher. Over time, basic knowledge and beliefs about teachers, teaching, and programs develop study and learning. The initial professional load is later shaped by formal experiences and informal, when teachers enter the track of teacher training and practical work.

Reeves, Turner, Morris, and Forde (2005) emphasize the social and collective aspects of the professional development of the teachers. They claimed that there is a complex dynamic in the process of learning and changing, and that people cannot learn and change without participating and facing others in a given framework. He argues that in order to create learning conditions, effective donors must understand the processes involved in the real change among all the officials, as these conditions that bring about change involve collective efforts. A continuous process of training and development and acquiring knowledge and skills of professionals is an essential component of improvement in all subjects.

One of the important factors in improving all the professions is the ongoing professional development of new professionals by acquiring new knowledge and funding. In the education system, it is very important to 
focus on improving teachers' skills and performance. Effective professional development should occur on a daily basis at school, and must be appropriate for the unique needs of the school and continues over time. Moswela (2006) indicates that there is a very strong connection between professional development and organization effectiveness. In this context, leadership is crucial to improving learning and work in organizations.

\section{The Research Hypotheses}

In the light of literary review, the hypotheses below had been examined:

H1. There is a positive relationship between transformational leadership and the professional development of teachers.

H2. There is a positive relationship between transactional leadership and the professional development of teachers.

H3. There is no relationship between laissez-fair leadership and the professional development of teachers.

H4. There is a positive relationship between professional development and teaches practice.

\section{Results}

This research conducted in a sample consists of 306 teachers from 22 schools in Bedouin aria in the Negev south of Israel, in addition, 10 principals as a part of Ph.D. study. For data collection two existing and validated questionnaires had been used, which relied on two previous research works. The first, "Multi-Facto Leadership Questionnaire", is based on a previous research work by Kurland (2006). The second is professional development questionnaire which is based on a previous research by Aminudin (2012); In addition, an interview was used to collect information from 10 school principals.

\section{Background Variables}

The sample consists of 306 teachers in which $57 \%$ are males and $43 \%$ are females, about $80 \%$ of them are aged below 40 years old, seniority in education; more than half have less than 10 years of experience. And $65 \%$ of them have the bachelor degree and only 3.3 are not academic. Moreover the positions of more than $57 \%$ of them are educators (157 educators). In addition, 10 schools principals from different schools in Bedouin area in the Negev had been interviewed.

The study showed important results on the relationship between the methods of leadership and professional development and the impact of professional development on the work of teachers.

Hypothesis one: There is a positive relationship between the transformational leadership and the professional development of teachers.

In order to examine the relationship between the transformational leadership and the professional development of teachers, the Pearson correlation test was conducted to determine.

According to Table 1, the professionalism, $r=0.007, p$-value $=0.457$, given that $\infty=0.05$. Since $p$-value $<$ 0.05 , the result is not statistically significant and a conclusion was made that, there is no significant relationship between the transformational leadership and the professionalism.

Table 1

Correlation Between Transformational Leadership and the Professionalism of Teachers

\begin{tabular}{lll}
\hline Variables & $\mathrm{R}$ & $P$-value \\
\hline $\begin{array}{l}\text { Transformational leadership } \\
\text { Professionalism }\end{array}$ & 0.007 & 0.457 \\
\hline
\end{tabular}


Hypothesis two: There is a positive relationship between the transactional leadership and the professional development of teachers.

According to Table 2, the transactional leadership, $\mathrm{r}=0.064, p$-value $=0.152$, given that $\infty=0.05$. Since $p$-value $>0.05$, the result is not statistically significant and a conclusion was made that, there is no significant relationship between the transactional leadership and the professional development.

Table 2

Correlation Between Transactional Leadership and the Professionalism of Teachers

\begin{tabular}{lll}
\hline Variables & $\mathrm{R}$ & $P$-value \\
\hline Transactional leadership & 0.064 & 0.152 \\
Professional & & \\
\hline
\end{tabular}

Hypothesis three: There is no relationship between the laissez-fair leadership and the professional development of teachers.

According to Table 3, the laissez-fair leadership, $r=0.115, p$-value $=0.065$, given that $\infty=0.05$. Since $p$-value $>\infty$, the result is not statistically significant and a conclusion was made that, there is no significant relationship between the laissez-fair leadership and the professionalism of the teachers.

Table 3

Correlation Between Laissez-fair Leadership and Professional Development of Teachers

\begin{tabular}{lll}
\hline Variables & $\mathrm{R}$ & $P$-value \\
\hline Laissez-fair leadership & 0.115 & 0.065 \\
Professional development & & \\
\hline
\end{tabular}

Hypothesis four: There is a positive relationship between the professional development and the teaching practice in Bedouin secondary schools.

According to Table 4, $t=19.755, p$-value $=0.000$, given that $\infty=0.05$. Since $p$-value $<0.05$, the result is statistically significant and we conclude that there is a significant relationship between the professional development and the teaching practice, and since the mean is high and equals 3.91, we can conclude that the professional development has a positive relationship with the teaching practice of the teachers.

Table 4

One-Sample T Test on Professional Development Experiences Have Some Influence Teachers' Practice (Test Value $=3$ )

\begin{tabular}{lllll}
\hline$t$ & $\mathrm{n}$ & Mean & Stranded deviation & $P$-value \\
\hline 19.755 & 257 & 3.9070 & 0.73746 & 0.000 \\
\hline
\end{tabular}

\section{Interviews Analysis}

The great challenge schools are currently facing is to provide quality education for students. Research shows that teachers are the important resource in education and they play a major and important role in improving and changing the education. The human resource is the most important resource in the development and promotion of the school, so investing in teachers' training may have a more positive effect than investing in physical resources in schools and the education system.

There are two types of the professional development: school training courses and regional training courses. Most of the principals told that they forced teachers to participate in the regional training courses. There is a 
whole set of training courses in all subjects and it is necessary to participate in these courses to improve the teachers' practice and to be updated with the new study programs. The second type is the school training courses which are also compulsory. The regional training courses take place in the teachers' center and teachers' training collages. The regional training courses include: subject training courses and training courses for implementing programs of the Ministry of Education. The schools training courses include: teachers' room where they learn and discuss issues important for school and the teachers, also courses for teachers' empowerment technology using courses and alternative assessment.

Principals told that all the teachers are obliged to participate in professional development unless the teachers are studying for an academic degree. Teachers who do not participate in the professional development assist negatively and that will hurt their advancements in the future.

Principals told that they do not take part in the regional training courses and they do not monitor teachers in these courses, this role is done by the subject coordinator specializing in this subject and he is responsible for monitoring the teachers in these courses. These training courses do not provide answers to all school requirements. Principals told that there are many issues which are not clear to teachers and there are no training courses which deal with these issues.

Most of the principals told that they encourage teachers to study and get their second degree. Sometimes the teachers' learning comes at the expense of the teachers' work, despite this, the principals help teachers to learn and they adapt the school system to the teachers' demand. Principals believe that teachers with high degrees can contribute to the school, increasing the students' achievement and improving the school effectiveness.

\section{Discussion}

\section{Leadership Styles and Professional Development}

The first hypothesis expects that a positive relationship between the transformational leadership and the professional development of the teachers has been rejected because the result is not statistically significant and a conclusion was made that there is no significant relationship between the transformational leadership and the professionalization of teachers.

According to the literature, the transformative leader handles with his/her subordinates individually to nourish their feelings and their personal needs, and to develop their growth and self-realization. The transformative leader serves among other things, as a wise and a loyal consultant for his subordinates, and as a supporter to their professional development. These features present the conclusion that the transformative leader can influence the professional development of the teachers, but the situation in the Bedouin secondary schools, especially and in the Israeli educational system in general is different.

The professional development in the Israeli education system is administered by the Ministry of Education in all aspects: budgeting, planning, and execution. According to the goals of the Ministry of Education, the professional development is intended to improve the teaching staff by expanding their horizons and through educational follow-up programs in various subjects. The Ministry of Education provides compensation for professional development by bonuses in teachers' wages that are based on collective agreements. Teachers get bonuses in wages only for the professional development and studies into educational institutions recognized by the Ministry of Education for this purpose. From what has been said above, there is no role for the principals in the professional development program. The professional development program usually is determined according 
to the vision of the officials in the Ministry of education. It is determined in general, without taking into account the specificities of the schools, especially the privacy of the Bedouin community. This problem raises also in the Bedouins teachers' respondents who have reported, that one of the difficulties that they encountered as they practiced the new knowledge and skills acquired in the professional development course is that the content of the professional development courses is not appropriate for the Bedouin culture. The principal cannot influence the professional development program, cannot adjust the professional development to suit school needs, the principal then can't be the wise and loyal consultant for his/her subordinates. He neither can support teachers' professional development, simply because the professional development is carried out by educational institutions recognized by the Ministry of Education. Because the professional development program is determined by the Ministry of Education therefore, the principals and the teachers are not partners in determining the content of the professional development.

The teachers usually participate in the professional development programs to get the financial rewards (bonuses) of the professional development courses (every 112 hours are equal to $1.2 \%$ from the teacher wage and he/she can accumulate $30 \%$ from their wage).

In the report of the State Comptroller in 2003, it was determined that the Ministry of Education did not include the criteria for eligibility to financial rewards for the professional development. It adds, that there is a need for a balance between the professional development in the teachers' professional field and the professional development for personal enrichment, that entitle the teacher a financial reward in a field that does not belong to the teacher's role or to the needs of the framework.

In light of this report, part of the professional development courses has become school courses, but the principal and the school management are not qualified enough to prepare appropriate courses for school needs. Usually, the school management chooses courses from the list that Ministry of Education supplies, and not necessarily courses that meet the school needs.

The second hypothesis expects a positive relationship between the transactional leadership and the professionalization of the teachers has been rejected.

The transactional leadership is a style of leadership whose purpose is driven by obedience to the leader's orders, through punishment and reward. The main reason that the teachers in the Bedouin educational system, as a part of the state educational system, participate in the professional development is the financial rewards, this is an appropriate issue for the transactional leader, but in the Bedouin secondary schools and in all schools of the state the principal is not responsible for the professional development reward. The teacher gets it from the Ministry of Education, the principal is not a part of the professional development system and he/she can't influence the teacher professional development, therefore there is no relationship between the transactional leadership and the professional development.

The third hypothesis expects that there is no relationship between the laissez-faire leadership and the professionalism of the teachers and the hypothesis has been accepted because the result is not statistically significant and there is no significant relationship between the laissez-faire leadership and the professionalization of the teachers had been found.

The laissez-faire style is "an Abdicates responsibility avoids making decisions", this inactive leadership prevents every attempt from influencing. The subordinates of this leader don't receive guidance or support, and typically show indifference and carelessness and tend to focus on achieving their personal goals, even if they are in conflict with the objectives of the organization or the group (Bass, 1985). According to the data, about a 
quarter of the teachers in the Bedouin secondary schools participate in the professional development courses that do not agree with the needs of their framework. The teachers in the Bedouin secondary schools in this case are focusing on achieving their personal goals. So, they participate in the professional development to accumulate financial rewards, they don't take into account the needs of their school or the students. The teachers participate in the professional development for personal enrichment that gives them bonuses, in courses that do not belong to the teachers' role or the needs of their framework (Kin, 2008), this kind of the professional development does not support the teachers' practice or the students' achievement.

The principal's interview results are not consistent with the data analysis of the questionnaires, principal in Bedouin secondary schools attach great importance for teachers' professional development and it is one of the standards that take into account in teacher promotion. Most of the principals told that they forced the teachers to participate in the regional training courses. The difference probably stems from that the role of the principal in professional development is only an intermediary and informational role. The Ministry of Education calls or sends an email to the principal informing him that there is training and requires that his teachers participate in these courses. He informs teachers and sometimes he forces teachers to participate in professional training under pressure from the Ministry of Education. The teachers know that the demand comes from the Education Ministry; therefore they do not attribute the matter of professional training to the principal.

Principals told that every teacher must participate in the professional development unless he is studying for a degree. Teachers who do not participate in the professional development assist negatively and it will hurt his advancement in the future.

The inconsistency between the questionnaire data and the interview data apparently stems from this that most of the principals behaved the same in related to the professional development regardless of the leadership style that they used in school management. Another reason is related to the professional development managing. The professional development benefits are determined and paid by the Ministry of Education. The principal role in the professional training isn't clear and it is apparent only to inform and to direct teachers for the professional development courses. Most of the principals told that they encourage teachers to learn for second degree. Sometimes the teachers' learning comes at the expense of the teachers' work, despite the fact that these principals help teachers to learn and adapt the school system to the teachers' demand. Principal believes that teacher with high degrees can contribute to the school and increasing the student achievement and improving the school work.

No researches were found in which to examine the relationship between the leadership styles and the teachers' professional development. But many researches indicate the important role of the principal in the professional development. Researches indicate that many teachers agree that the schools principals play a "vital", "crucial", and "important" role in their development. Principals need to set the example and take the lead for growing and development. Teachers require principals to keep abreast of the school developments. Furthermore, principals need to be in touch with their teachers, identify their shortcomings, and see where they can "plant and plough in them".

Moswela's (2006) study shows that the principals who create the professional development opportunities that revitalize teachers' passion for learning and development will support their growth and also enhance teaching. For the sake of effectiveness this means that principals also have to monitor and evaluate the teaching processes, especially after professional development programs in order to take appropriate action.

Principals told that they do not take part in the regional training courses and they do not monitor the 
teachers in these courses, this role is done by the subject coordinator who specialized in this subject and he is the responsible for monitoring the teachers in these courses.

In the Bedouin education system and in the educational system of the state in general, the principal is not involved in the professional development programs, so the teachers do not get feedbacks or monitor their professional development they need for good teaching practices. Teachers need feedbacks and monitoring after the professional development programs to assist them in the implementation of the acquired knowledge and skills in their working with their students. One of the most prominent faults in the teachers' professional patterns used today in the Israeli professional development system is isolation of these professional developments from school life, and the isolation of the trainee teacher from his colleagues in school. Therefore, the researchers point out that such training must include personal planning of each teacher, planning as part of the school, a great contribution from the Ministry of Education, academies and the continuous interaction between these components.

Literature reviews have identified three factors that lead to a positive change in the teaching among teachers: leadership, planning and preparation and practice development, all together should emphasize the role of leadership in igniting, implementing, and issuing change. There is a need for an effective planning and preparation to provide a structure and context for teachers wishing to implement the change.

\section{Professional Development and Teaching Practice}

The fourth hypothesis that expects that the professional development has a positive impact in the teaching practice has been accepted.

According to the data, the teachers' professional development in Bedouin schools affects the teachers' practice. The result is statistically significant and the professional development influenced the teaching practice in Bedouin high schools positively.

The interview with the principals indicates that most of the principals encourage teachers to study for second degree. Principal believes that the teacher with high degrees can contribute to the school and increasing the students' achievement and improving the school work.

This result is consistent with the findings of Borko and Putnam (1995) who offer evidence which supports the fact that the professional development plays an important role in changing teaching practice, and that the changes have positive impact on students' achievements. They add that for teachers to change their teaching practice they would need to expand and to develop their knowledge systems.

The professional development of the teachers in Bedouin secondary schools has developed teachers' knowledge and skills, improved their teaching practice, and raised the students' performance. Professional development is the most effective when it is a continuous process that involves appropriately planned development and follow-up through supportive feedback and observation, staff dialogue, and peer coaching. Professional growth in the teachers occurs when a professional development program acknowledges teachers' needs. The professional development causes an improvement of the professional identity and the empowering of the professional functioning in the classroom, and contributes to the achievement of the school goals. The principal who is the direct superior of the teacher and that the employee is responsible and committed to his development, empowerment, increasing of his self-esteem, expanding of his horizons and construction of his social and values worldview, all of these are important components of teachers' professional development.

Researchers found that the principal's guiding leadership is a key variable in the effectiveness of the 
school. His leadership is expressed in the activities of support, guidance of the teachers, creation of linkages between school policy and the needs of teaching and learning in the classroom by the involvement in the class activities and strengthening of the control of the teacher as a professional.

\section{Conclusion}

An important finding in this study is that there was no connection between the leadership styles and professional development. The explanation for this fact is that the Ministry of Education is the sole director of the professional development. The principal in the Bedouin high school does not have a significant part in the professional development, despite the important role of the principal, which emerges from the professional literature.

Another finding is that the Bedouin principals did not monitor the effect of the professional development on the teaching of the Bedouin teachers. Follow-up remains in the hands of the teachers themselves who assess the improvement in their teaching independently; literature emphasizes the importance of the role of the principal in supervising and evaluating teachers' teaching in order to know the improvement in teachers' teaching, particularly after the participation of teachers in studies and courses in the professional development and to take the appropriate action when it is necessary.

An important finding of the study is that the professional development affects positively teachers' practice; these results are supported by the literature which found a significant connection between professional development and changes in teachers' practice, and that the expansion of teachers' knowledge is a necessary factor for creating change in teacher's practice.

In the light of these results the study suggests these recommendations: Professional development is a very important factor in improving the practice of the teachers. For effective professional development, there is a need to give principals and teachers an opportunity to participate in the selection and planning the topics of the professional development. It is important that these courses meet the needs of schools and teachers.

The study results indicate that there is a lack in assessing the teachers' professional development and its impact in teachers' practice; managers should monitor the application of the professional development in teachers' teaching in order to gain the benefit of professional development.

\section{References}

Aminudin, A. N. (2012). Teachers' perceptions of the impact of professional development on teaching practice: The case of one primary school. Unitec Institute of Technology, England.

Alksaalh, B. (2008). Nature of the relationship between teacher and student in the Bedouin sector. The Ministry of Education, Beer-Shiva.

Bass, B. M. (1985). Model of transformational leadership. In T. F. Mech and G. B. McCabe (Eds.), Leadership and academic librarians (pp. 66-82). Westport, CT: Greenwood.

Bennis, W., \& Nanus, B. (1985). Leaders: The strategies for taking charge. Collins Business Essential, New-York.

Bolam, R. (2003). Professional development and professionalism. In T. Bush and L. Bell (Eds.), The principles and practice of educational management (pp. 103-118). London: Paul Chapman Company.

Borko, H., \& Putnam, R. (1995). Expanding a teacher's knowledge base: A cognitive psychological perspective on professional development. In T. Guskey and M. Huberman (Eds.), Professional development in education: New paradigms and practice (pp. 35-61). NY: Teachers College Press.

Carter, K. (1993). The place of the story in the studying of teaching and teacher education. Educational Researcher, 22(1), 5-12.

Desimone, L. M., Smith, T. M., \& Ueno, K. (2006). Are teachers who need sustained, content-focused professional development getting it? An administrator's dilemma. Educational Ministration Quarterly, 42(2), 179-215. 
Desimone, L. M. (2009). Improving impact studies of teachers' professional development: Toward better conceptualizations and measures. Educational Researcher, 38(3), 181-199.

Drago-Severson, E., Blum, J., \& Asghar, A. (2011). Learning and leading for school transformation: Lessons from practicing leaders on building human capacity. Leadership in Focus, 24, 38-40, Victoria, Australia.

Hassel, E. (1999). Professional development: Learning from the best, a toolkit for school and district based on the notional awards program for model professional development. Oak brook, IL: North Central of Regional Educational library.

Hargis, M. B., Wyatt, J. D., \& Piotrowski, C. (2001). Developing leaders: Examining the role of transactional and transformational leadership across contexts business. Organization Development Journal, 29(3), 51-66.

Luthans, F. (2005). Organizational behavior (10th ed.). New York: McGraw-Hill, Irwin Publication.

Kin, H. (2008). Teacher training: The connection between the subject of the course and the training teacher's professional field. Research and Information Center. www.knesset.gov.il $/ \mathrm{mmm}$

Kula, A., \& Globman, R. (1994). To be a principal and succeed. Even-Yehuda, Rechess Publishing (in Hebrew).

Kurland, H. (2006). Organizational learning as a result of the leadership and vision, and its contribution to the investment of effort, satisfaction from teachers and obtain educational elementary schools. University of Haifa, Israel.

Lee, H. L. (2005). Developing a professional development program model based on teachers' needs. The Professional Educator, Spring, XXVII(1 and 2), 39-49.

Maughan, S., Teeman D., \& Wilson, R. (2012). What leads to positive change in teaching practice? National Foundation for Educational Research, Slough, NFER, www.Nfer.ac.uk

Mewborn, D. S., \& Huberty P. D. (2004). A site-based model for professional development in mathematics at the elementary school level. Pythagoras, 59, 2-7.

Moswela, B. (2006). Teacher professional development for the new school improvement: Botswana. International Journal of Lifelong Education, 25(6), 623-632.

Murtaza, K. F. (2010). Teachers' professional development through whole school improvement program. International Journal of Business and Social Science, 1(2), 213-221.

Reeves, J., Turner E., Morris, B., \& Forde, C. (2005). Changing their minds: The social dynamics of school leaders' learning. Cambridge Journal of Education, 3(2), 253-273.

Robbins, S. P., \& Coulter, M. (2007). Management (9th ed.). London: Prentice-Hall.

Steyn, G. M. (2011). Continuing professional development in South African schools: Staff perceptions and the role of principals. Journal of Social Science, 28(1), 43-53.

Vonk, J. H. S. (1995). Becoming a teacher, brace yourself. Singapore: Institute of Education. 